\title{
Asap Cair dan Biochar hasil Proses Pyrolisis Sekam Padi dan Biomassa lainnya sebagai Income Generating Unit di Universitas Tribhuwana Tunggadewi
}

\author{
Taufik Iskandar ${ }^{1)}$ dan Ayu Chandra Kartika Fitri ${ }^{2}{ }^{2}$ \\ 1) 2) Program Studi Teknik Kimia, Fakultas Teknik, Universitas Tribhuwana Tunggadewi, Malang, \\ *Email Corresponding author : ayu.chandra@ unitri.ac.id
}

\begin{abstract}
Proses Pyrolisis biomasa menghasilkan Asap cair dan Biochar. Hasil analisa terhadap proses produksi Asap Cair dan Biochar melalui Proses Pyrolisis memiliki profitabilitas yang tinggi sehingga usaha ini mempunyai prospek yang menjanjikan dan pasar yang sangat terbuka lebar. Asap Cair yang telah ada dipasar, diproduksi dari bahan baku tempurung kelapa dengan penggunaan terbanyak untuk koagulan karet dan sedikit sekali untuk kebutuhan pangan. Belum ada perusahaan manapun di Indonesia yang secara spesifik menjual produk biochar atau memasarkannya. Tujuan kegiatan ini adalah memproduksi asap cair dan biochar dengan bahan baku utama sekam padi dan bahan baku pengganti antara lain tongkol jagung, jerami jagung, jerami padi, gergajian kayu, limbah bambu, dan limbah biomassa lainnya dengan menggunakan metode teknologi proses pyrolisis. Hasil yang diperoleh meliputi produk asap cair yang terbagi dalam 3 (tiga) grade yang disesuaikan dengan karakteristik dan sifat-sifat fungsional dari senyawa penyusunnya. Keunggulan yang dikembangkan adalah tidak memilih asap cair sebagai koagulan karet tetapi sebagai pengawet makanan dan insektisida. Sedangkan biochar dijual langsung sebagai bahan perbaikan tanah pertanian terdegradasi dan untuk energi alternatif dalam bentuk bio-bricket.
\end{abstract}

Kata kunci : asap cair; biobriket; bio-char; biomasa; pyrolysis

\begin{abstract}
The pyrolysis process of biomass produces liquid smoke and biochar. The Liquid Smoke and Biochar production processes analysis through the Pyrolysis Process has high profitability, so this business has promising prospects and a very wide-open market. Liquid smoke on the market is produced from coconut shells as raw material, with the most use for rubber coagulants and very little for food purposes. There is not a single company in Indonesia that explicitly sells biochar products or markets them. This activity aims to produce liquid smoke and biochar with rice husks primary raw materials and substitute raw materials in corn cobs, corn straw, rice straw, sawn timber, bamboo waste, and other biomass wastes pyrolysis process technology method. The results obtained include liquid smoke products divided into 3 (three) grades adjusted to the constituent compound's characteristics and functional properties. The advantage developed is that it does not choose liquid smoke as a rubber coagulant but as a food preservative and insecticide. Meanwhile, biochar is sold directly as a repair material for degraded agricultural land and alternative energy in the form of bio-brickets.
\end{abstract}

Keywords : biobriquette; bio-char; biomass; liquid smoke; pyrolysis 


\section{PENDAHULUAN}

Proses Pyrolisis menghasilkan Asap cair dan Biochar. Kedua komoditas ini mulai dikenal oleh masyarakat karena karakteristik dan sifat-sifat fungsionalnya. Hasil analisa terhadap proses produksi Asap Cair dan Biochar melalui Proses Pyrolisis memiliki profitabilitas yang tinggi sehingga usaha ini mempunyai prospek yang menjanjikan dan pasar sangat terbuka lebar. Begitu pula faktorfaktor lain yang menentukan tingkat profitabilitas seperti persaingan dalam industri, daya tawar pembeli, daya tawar pemasok, ancaman pemain baru serta ancaman barang substitusi tidak menjadi penghambat yang serius.
Pusat Kajian dan Pengembangan Teknologi Tepat Guna dan Energi UNITRI selama ini hanya memproduksi Asap Cair dan Biochar dengan skala kecil karena peralatan yang digunakan masih skala laboratorium. Untuk memenuhi permintaan yang semakin banyak, maka perlu meningkatkan kapasitas produksi, perencanaan usaha yang terstruktur dan memiliki legalitas formal.

Bahan baku yang diperlukan adalah Sekam padi dan tongkol jagung sebagai bahan baku penggantinya. Proses produksi Asap Cair dan Biochar menggunakan teknologi Slow Pyrolisis dilakukan di Pusat Kajian dan Pengembangan Teknologi Tepat Guna dan Energi dengan uraian secara singkat sebagai berikut :

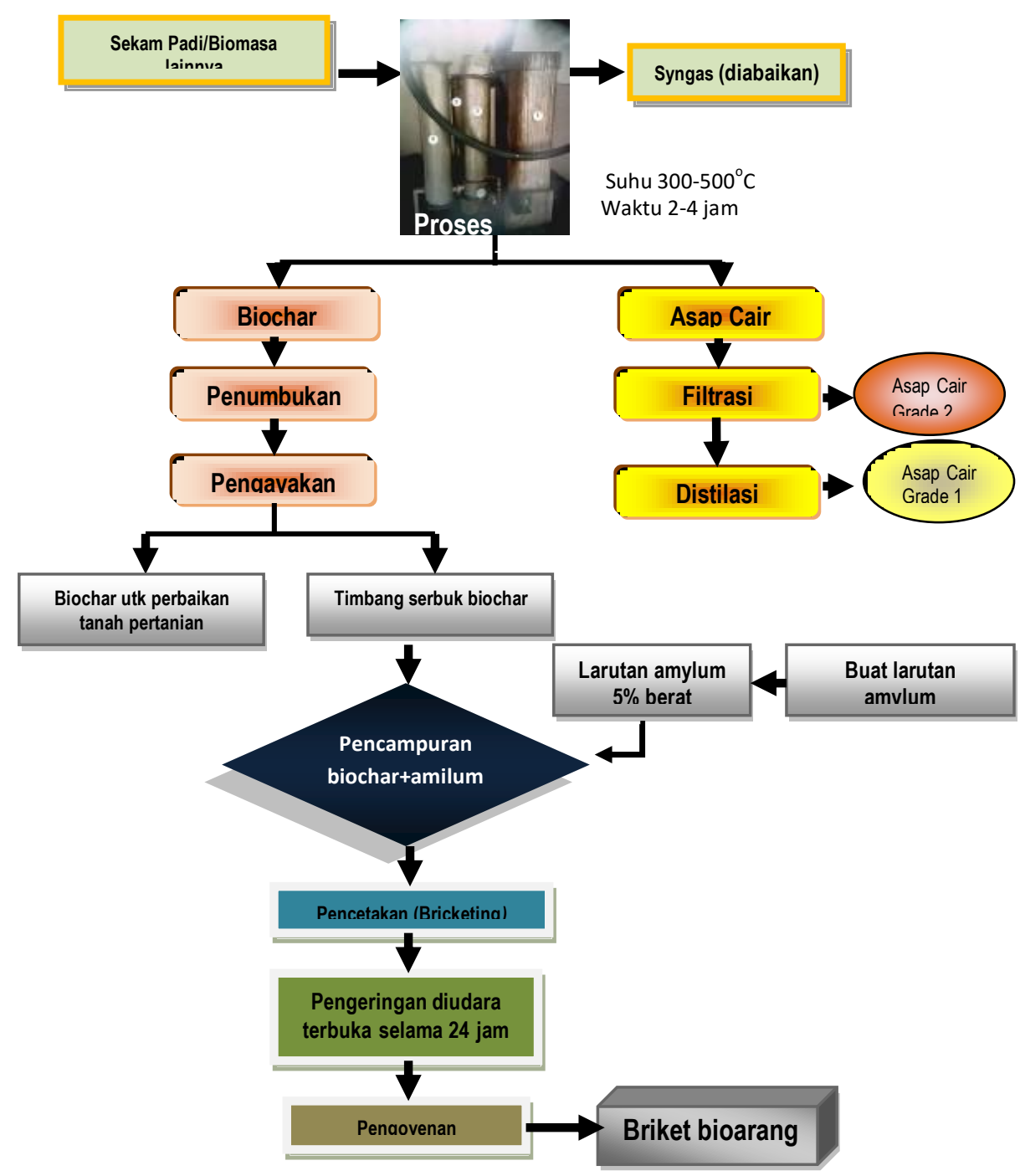

Gambar 1. Diagram Alir Proses Produksi Asap Cair dan Biochar 
Pengaturan dan perencanaan terkait ketersediaan bahan baku sekam padi, tongkol jagung maupun bahan jadi dicatat agar proses produksi bisa berjalan dengan baik dan mampu menghasilkan produk Asap Cair dan Biochar sesuai yang diminati oleh konsumen. Di bidang pemasaran, kreatifitas, inovasi dan sosialisasi selalu dilakukan mengingat produk Asap Cair dan Biochar bukan merupakan kebutuhan pokok masyarakat. Proses penyaluran barang pada konsumen dirancang hanya untuk pembelian dengan kapasitas banyak. Pengelolaan sirkulasi keuangan dilakukan secara transparan termasuk bagaimana keuangan mampu dibagikan sesuai dengan anggaran yang dimiliki. Pembukuan kegiatan dilakukan dengan pencatatan uang keluar masuk baik untuk biaya produksi, perawatan alat, maupun ongkos perjalanan. Kegiatan ini dilakukan oleh Bendahara dan hasilnya dilaporkan ke atasan yang berwenang di PT pengusul.

Perkiraan target pasar yang potensial menerima produk Asap Cair dan Biochar dari PPUPIK ini adalah masyarakat petani, nelayan dan UMKM yang bergerak di bidang pangan seperti warung penjual bakso, soto, sate dan warung makan yang lain di sekitar kampus dan wilayah Malang raya umumnya. Teknik penjualan, marketing, biaya penjualan produk dan tingkat sosial-ekonomi konsumen juga menjadi target.

\section{METODE KEGIATAN}

Dari analisa situasi/ survey pasar, untuk produsen Asap cair, ada 2 perusahaan besar yakni Deorub dan Bioshell, selain itu juga ada dua UKM tetapi tidak memiliki merk dagang yang spesifik. Produk yang ditawarkan berupa asap cair untuk koagulan karet, dengan merk Deorub, asap cair yang berasal dari tempurung kelapa untuk keperluan pangan dan non pangan, dengan merk dagang Bioshell. Bioshell mengklaim masih belum dapat memenuhi kebutuhan dari industri karet yang berada di Kalimantan. Untuk UD Sinar Alam Jaya, Banyuwangi, menjual produk asap cair grade II dan III dari batok kelapa. Produk siap pakai tersebut digunakan untuk pengawetan ikan, daging, buah. Untuk CV Rahmad Paralim, Medan menjual produk asap cair terutama untuk pengental getah karet.

Dengan demikian, Asap Cair yang telah ada di pasar, diproduksi dari bahan baku tempurung kelapa dengan penggunaan terbanyak untuk koagulan karet dan sangat jarang untuk keperluan pangan. Sedangkan belum ada satupun perusahaan di Indonesia yang secara spesifik menjual produk Biochar atau memasarkannya.

Oleh karena itu dengan memperhatikan kondisi riil yang ada, Pusat Kajian \& Pengembangan Teknologi Tepat Guna \& Energi UNITRI berkeinginan untuk mengembangkan hasil proses Pyrolisis ini menjadi Income Generating Unit Universitas dengan kegiatan utama memproduksi Asap Cair sebagai pengawet makanan, penambah rasa dan sebagai insektisida/herbisida, bukan sebagai koagulan karet. Sedangkan Biochar dijual sebagai bahan perbaikan tanah terdegradasi dan diproses lebih lanjut sebagai energi alternatif pengganti gas dan minyak tanah berupa Bio-bricket. Universitas Tribhuwana Tunggadewi Malang sudah melakukan produksi asap cair dan biochar dengan bahan baku utama Sekam Padi dan bahan baku pengganti antara lain tongkol jagung, jerami jagung, jerami padi, gergajian kayu, 
limbah bambu, dan limbah biomassa lainnya. Produk Asap Cair yang dihasilkan dibagi dalam 3 (tiga) grade yang disesuaikan dengan karakteristik dan sifatsifat fungsional dari senyawa penyusunnya.

\section{KARYA UTAMA}

Unit Reaktor Pyrolisis tempat berlangsungnya proses pyrolysis dimana senyawa organik dalam biomassa didekomposisi melalui pemanasan menggunakan sedikit oksigen menjadi produk berupa padatan/char $(10-20 \% \mathrm{w})$, gas $(10-30 \% \mathrm{w})$, dan cairan organik (4065\% w). Liquid smoke atau Asap Cair merupakan suatu cairan organik hasil kondensasi uap pada proses pirolisis. Senyawa-senyawa yang terkandung di dalamnya mempunyai sifat-sifat fungsional yang beragam antara lain : 1). Senyawa fenol, merupakan antioksidan yang bermanfaat untuk mencegah proses oksidasi senyawa lemak dan protein, dan memperpanjang umur simpan produk makanan. 2). Senyawa karbonil, dalam asap cair berfungsi untuk pewarnaan dan citarasa produk asapan. 3). Senyawa asam, berfungsi sebagai anti bakteri / anti mikroba yang dapat menghambat penguraian dan pembusukan produk asapan dan membentuk citarasa produk asapan.

Bio-arang (Bio-char) adalah padatan yang sangat porous hasil dari proses pirolisis. Produk ini dikenal sebagai Bioarang (bio-char) dan biochar ini berbeda dengan arang yang biasa dipakai oleh masyarakat sebagai bahan bakar. Bio-char merupakan karbon organik yang tahan terhadap dekomposisi, tekstur berpori, halus, serta sedikit bersifat alkali. Biochar merupakan bahan yang kaya karbon dan mempunyai

rumus

kimia

C12.91H6.05NO3.53 dengan kepadatan sekitar $467 \mathrm{~kg} / \mathrm{m}^{3}$, rasio $\mathrm{H} / \mathrm{C} 0,47$ serta $\mathrm{O} / \mathrm{C}$ $<0,30$ dan nilai pemanasan 25,3 MJ/kg [1]. Biochar mengandung $17.60 \%$ abu, $18.70 \%$ zat yang mudah menguap, dan $63.70 \%$ karbon tetap. Bio-char hasil produksi Pusat Kajian dan Pengembangan Teknologi Tepat Guna dan Energi UNITRI telah digunakan untuk kegiatan pertanian dan pengembangan energi alternatif.

\section{ULASAN KARYA}

Metode yang digunakan adalah teknologi proses pyrolysis. Unit Pyrolisis ini terdiri dari reaktor pirolisis yang merupakan alat pendekomposisi senyawasenyawa organik melalui proses pemanasan pada suhu tinggi yaitu $300-500^{\circ} \mathrm{C}$ tanpa berhubungan langsung dengan udara luar. Reaktor pirolisis diisolasi bagian luarnya dengan bata dan tanah untuk mencegah panas yang ada dalam reaktor keluar secara berlebihan, kemudian dilengkapi dengan alat penangkap tar (Cyclon) dan seperangkat alat kondensasi, yang bisa dilihat pada Gambar 2 berikut.

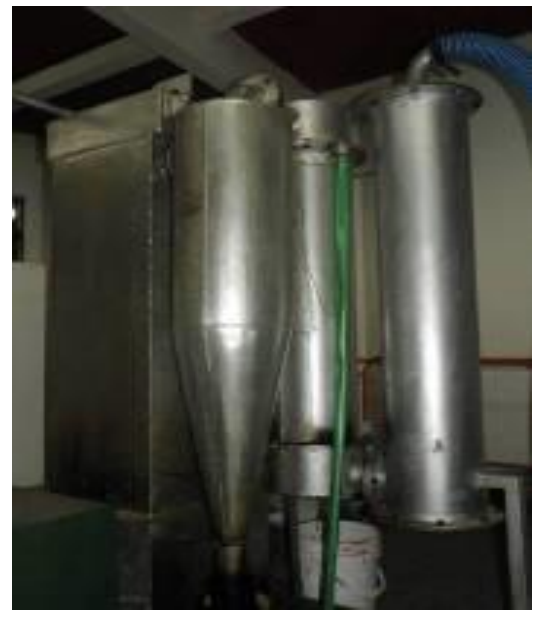

Gambar 2. Unit Pyrolisis di Univ. Tribhuwana Tunggadewi, Malang 
Asap Cair (Liquid Smoke) hasil produksi Pusat Kajian dan Pengembangan TTG dan Energi UNITRI dibedakan ke dalam 3 grade dan masing-masing grade telah disesuaikan dengan kegunaannya antara lain :

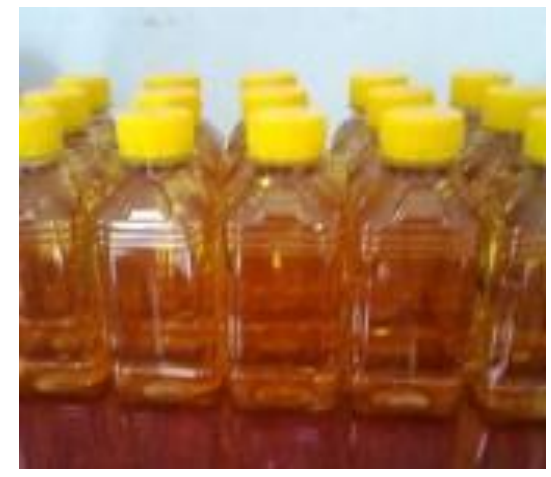

Gambar 3. Asap Cair Grade 1

Grade 1, Memiliki warna yang bening; rasanya sedikit asam; aromanya netral. Grade 1 ini bagus untuk industri pangan karena dapat menghambat perkembangan bakteri karena sifat antimikrobia dan antioksidannya. Peruntukan: pengawet makanan, daging, ikan dan bumbu

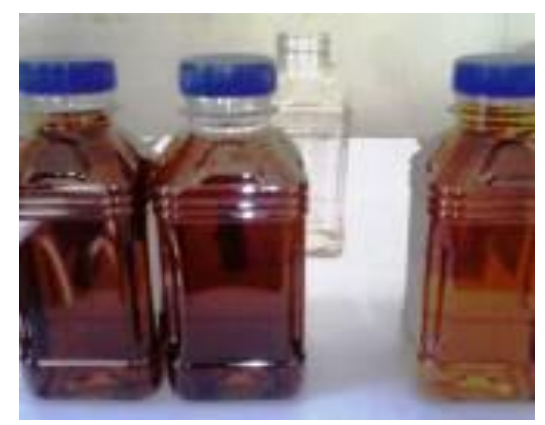

Gambar 4. Asap Cair Grade 2

Grade 2, Memiliki warna coklat transparan, rasanya Asam; aromanya Asap Lemah. Grade 2 ini berperan dalam pemberi rasa \& aroma yang spesifik, pengganti proses pengasapan tradisional yang memakai asap secara langsung. Peruntukan: 1). Makanan dengan rasa/aroma asap (Mie, bakso, tahu, ikan Asap/ bandeng asap, telur asap, bumbu barbeque). 2). Sebagai bahan baku untuk campuran produksi pupuk organik, dapat meningkatkan laju pertumbuhan tumbuhan, dapat mengendalikan gulma (Herbisida), anti bakteri (Pestisida), anti jamur (fungisida) dan dapat untuk mengusir serangga pengganggu (Insektisida) pada kegiatan pertanian.

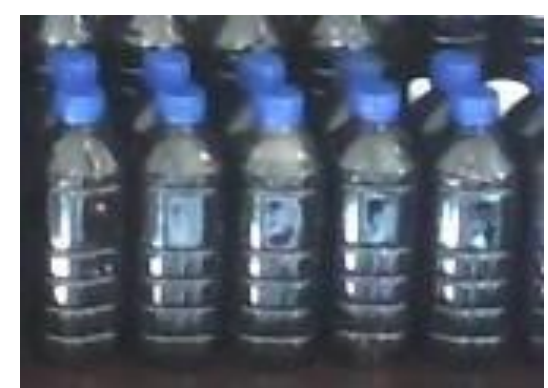

Gambar 5. Asap Cair Grade 3
Grade 3, memiliki warna Coklat Gelap; Rasanya Asam kuat; aromanya Asap Kuat; Grade 3 ini mempunyai sifat fungsional sebagai koagulan lateks. Digunakan sebagai penyamakan kulit, penggumpal karet pengganti asam semut, pengawet kayu dan pertahanan terhadap serangan rayap, pengganti Antiseptik untuk kain, virus, bakteri patogen, jamur dan protozoa. Asap cair bisa dipakai pada industri seperti : 1). Industri Obat Tradisional, yaitu dapat berfungsi sebagai anti septik sebagai obat sakit gigi, mengobati sakit kulit (herpes, kutu air, panu) dan mengobati luka diabetes yang diakibatkan oleh jamur, virus, bakteri, dengan cara mengoleskan pada bagian yang sakit. 2). dapat melenyapkan bau sampah, bau ikan, bau kandang ternak, bau WC umum, bau limbah ikan/udang dan limbah pabrik, bau semua jenis bangkai binatang, bau tak sedap di dalam ruangan, dapat mengurangi nyamuk dan lalat.

Biochar berbeda dengan arang tradisional yang ada di masyarakat, karena biochar mengandung karbon yang sangat 
stabil dan berfungsi menjadi pengikat karbon jika ditambahkan ke dalam tanah, yaitu dapat memperbaiki sifat tanah, yaitu meningkatkan kemampuan kapasitas penahan air [2], meningkatkan Kapasitas Tukar Kation (dapat memperbaiki kesuburan tanah) dan meningkatkan Kejenuhan Basa tanah, sekaligus bisa menambah unsur hara untuk memperbaiki daya serap unsur hara oleh tumbuhan [3]. Biochar juga menjadi alternatif dalam pemecahan masalah global warming melalui penurunan kadar karbon dioksida $\left(\mathrm{CO}_{2}\right)$ dalam udara/atmosfer.

Besarnya luas permukaan dan porositas biochar menjadikan biochar mampu menyerap atau meretensi unsur hara dan kandungan air dalam tanah. Biochar juga berfungsi menjadi habitat untuk tumbuhnya mikroorganisme yang menguntungkan [4], [5]. Dengan demikian Biochar memberikan peluang besar terhadap perubahan dari revolusi hijau kepada ekosistem agroteknologi yang berkelanjutan.

\section{DAMPAK DAN MANFAAT KEGIATAN}

Dampak dari kegiatan ini ditinjau dari

(1). Aspek Lingkungan, bahwasanya teknologi pirolisis dapat mengubah biomassa menjadi produk yang ramah lingkungan, dapat menurunkan tingkat $\mathrm{CO}_{2}$ di atmosfer, mengurangi volume biomassa, dapat diubah sebagai bahan bakar dan produk kimia. Sedangkan, manfaat Biochar dalam hubungannya dengan lingkungan adalah memberikan peluang besar terhadap perubahan dari revolusi hijau kepada ekosistem agroteknologi yang berkelanjutan. Kemudian (2) dari Aspek
Sosial Ekonomi, penggunaan teknologi Pyrolisis adalah solusi untuk terwujudnya usaha industri pengolahan yang menguntungkan, karena limbah biomassa dapat diproses menjadi produk yang menguntungkan dan bernilai ekonomis serta dapat meningkatkan pendapatan melalui produk yang dihasilkan. Dengan demikian bisa menambah kesempatan kerja bagi pengangguran, mewujudkan jiwa wirausaha di level pendidikan tinggi, memberikan pengalaman kerja kepada mahasiswa dalam mengembangkan karya, mendukung otonomi kampus melalui pemasukan pendapatan dari usaha jasa dan industri baik secara mandiri maupun bekerjasama/ bermitra. Program pengembangan teknologi Pyrolisis ini dapat meningkatkan kapasitas produksi, perencanaan usaha yang terstruktur dan memiliki legalitas formal.

\section{KESIMPULAN}

Kegiatan PPUPIK ini dapat berkontribusi pada bidang ilmu teknik kimia dan pertanian, khususnya dalam rekayasa teknologi tanpa limbah atau teknologi pyrolisis untuk menghasilkan produk asap cair yang berperan sebagai pengawet makanan dan produk biochar yang dapat memperbaiki tanah yang terdegradasi sekaligus berfungsi sebagai pupuk tanaman.

\section{PENGHARGAAN}

Penghargaan yang tinggi dan ucapan terima kasih disampaikan kepada DITLITABMAS DIKTI, L2DIKTI wilayah 7, Tim PPUPIK dan mahasiswa yang terlibat dan yang telah membantu dengan sungguh-sungguh, sehingga semua kegiatan 
dapat berjalan dengan lancar dan selesai tepat waktu.

\section{DAFTAR PUSTAKA}

[1] D. Özçimen and F. Karaosmanoğlu, "Production and characterization of bio-oil and biochar from rapeseed cake," Renew. Energy, 2004.

[2] K. Karhu, T. Mattila, I. Bergström, and K. Regina, "Biochar addition to agricultural soil increased $\mathrm{CH} 4$ uptake and water holding capacity Results from a short-term pilot field study," Agric. Ecosyst. Environ., 2011.
[3] J. Lehmann, "Terra preta nova Where to from here?," in Amazonian Dark Earths: Wim Sombroek's Vision, 2009.

[4] B. Glaser, J. Lehmann, and W. Zech, "Ameliorating physical and chemical properties of highly weathered soils in the tropics with charcoal - A review," Biology and Fertility of Soils. 2002.

[5] J. Lehmann, J. Gaunt, and M. Rondon, "Bio-char sequestration in terrestrial ecosystems - A review," Mitigation and Adaptation Strategies for Global Change. 2006. 